\title{
Studying Petrology and Determining Tectonic Setting of Bidkhan Area Southeast of Iran
}

\author{
Ahmad Adib' ${ }^{1}$ Alireza Ashofteh ${ }^{2}$ \\ ${ }^{1}$ Mining Engineering Department, Islamic Azad University South Tehran Branch, \\ Tehran, Iran \\ ${ }^{2}$ Young Researchers and Elite Club, Science and Research Branch, Islamic Azad University, Tehran, Iran \\ Email: adib@azad.ac.ir, st a ashofteh@azad.ac.ir
}

Received 8 July 2015; accepted 11 October 2015; published 14 October 2015

Copyright (C) 2015 by authors and Scientific Research Publishing Inc.

This work is licensed under the Creative Commons Attribution International License (CC BY). http://creativecommons.org/licenses/by/4.0/

(c) (i) Open Access

\begin{abstract}
Bidkhan region has an area of approximately $104 \mathrm{~km}^{2}$. This region includes all the heights and villages that are known by the name of Bidkhan. Chemical nomenclature of igneous rocks is performed with the help of main oxide plots. Based on the analysis results of the samples with minimum alteration, position of these samples was obtained on special diagrams. The achieved data should be compatible with field evidences at a regional scale. There are some limits to the interpretation of the harvested samples on chemical nomenclature diagrams for igneous rocks that should be taken into account. Lithology of Bidkhan region was performed using the main oxides that were obtained from XRF method. 30 sample rocks, which were very fresh and without alteration, were used for drawing diagrams and determining the position of these regional rocks on the chemical nomenclature diagrams for igneous rocks. The results for the analysis of the main oxides of these 30 samples are also presented.
\end{abstract}

\section{Keywords}

Bidkhan, Tectonic, Petrology, Rocks

\section{Introduction}

Bidkhan region is located in central Iran structural zone as a part of the Urumieh-Dokhtar magmatic arc which is evolved during the Arabia-Eurasia convergence. In this region, quaternary deformations were consistent with recent faults activities [1]-[5]. From a lithological perspective, Bidkhan region is divided into three distinct and 
separable parts. The exterior part, which is formed by volcaniclastic, volcanogenic, and sedimentary deposits and interior part, which is divided into two parts of central and the surrounding ring. These two internal parts are formed by volcanic and subvolcanic outcrops. They have an intermediate to acidic chemical composition. Moving from margins to the center, alteration intensity varies from low (propylitic) to severely altered (phyllic, alunite, advanced argillic and potassic) [6]. Altered rocks such as propylitics, phyllics, albites, sericites, argillics, alunites, kaolins, carbonates, silicas, advanced argillics, potassics and malachites exist in Bidkhan region and especially in the central part of this area. Alteration is a characteristic of this region. It is necessary to note that alteration is observed in this region from propylitic zone to phyllic, alunite and potassic. Several conditions and circumstances are necessary for an event to become the main phenomenon in a region. Alteration of the interior outcrops has developed geochemical as the main phenomenon. Without a doubt, this geochemical phenomenon has made Bidkhan region as one of the biggest severely altered integrated sets of Iran [7].

\section{Materials and Methods}

The position of Bidkhan rocks was studied on various diagrams Tas (Cox 1979) diagram: In which, $\mathrm{SiO}_{2}$ is on the horizontal axis and $\mathrm{Na}_{2} \mathrm{O}+\mathrm{K}_{2} \mathrm{O}$ are on the vertical axis. 30 samples were analyzed for this diagram (Figure 1). It can be observed that the rocks of this region are generally intermediate to acidic and vary from sub-alkaline to alkaline, which is a general trend. Based on the diagram, these rocks are in three ranges of trachyandesite, andesite and dacite, which is in accordance with microscopic and field observations [8].

Examining Tas (Le Bas 1986) diagram confirmed the results of the above diagram. Based on this diagram, these rocks are generally intermediate to acidic, sub-alkaline, and are placed within three ranges of trachyandesite, andesite and dacite (Figure 2) [9].

Tas (Middle Most 1994) diagram is newer than the previous ones. 30 analyzed samples are presented on the diagram to validate the previous diagrams. It is also observed in this diagram that these rocks were from three types of trachyandesite, andesite and dacite (Figure 3). It seems that magmatic origin of these rocks was andesitic and other trachyandesitic and dacitic rocks were created by other processes such as differentiation and digestion of walls from andesitic magma [10].

TAS (Cox et al. 1979)

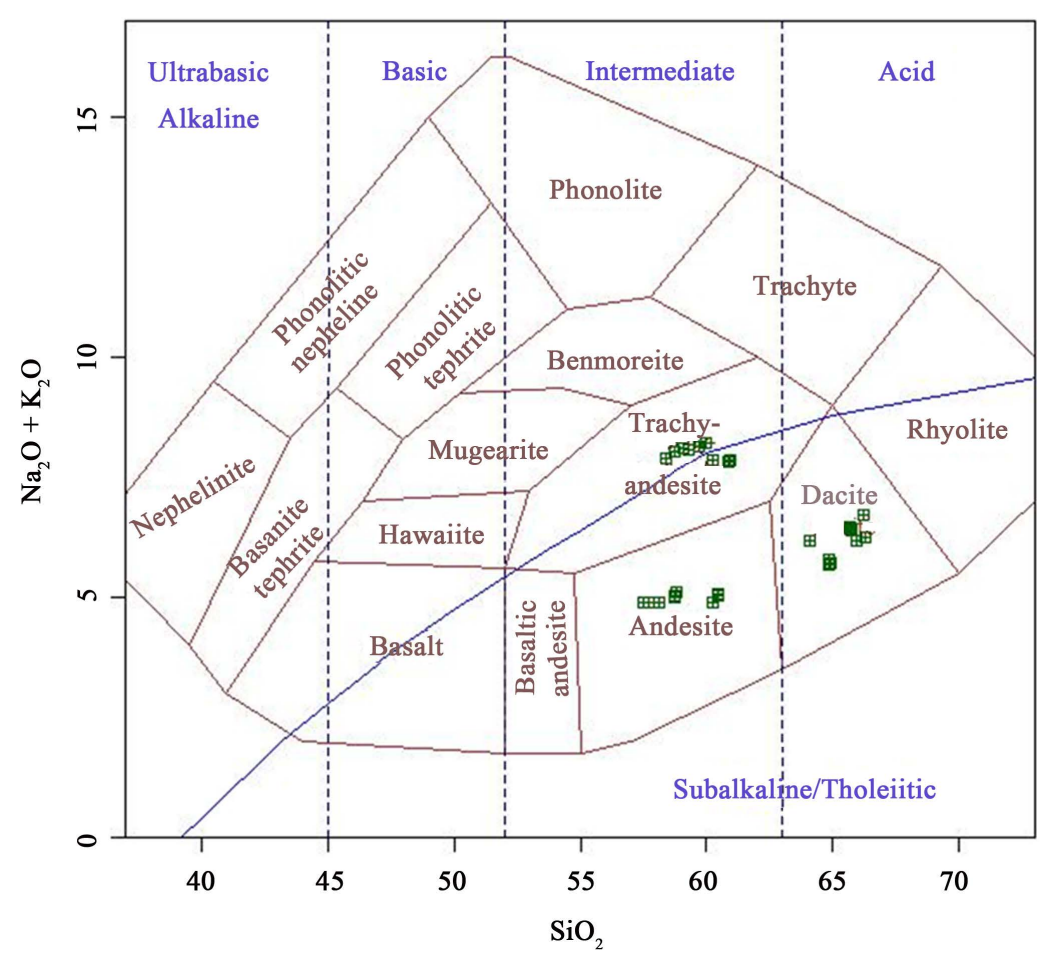

Figure 1. The position of Bidkhan rocks on Tas (Cox 1979) diagram. 


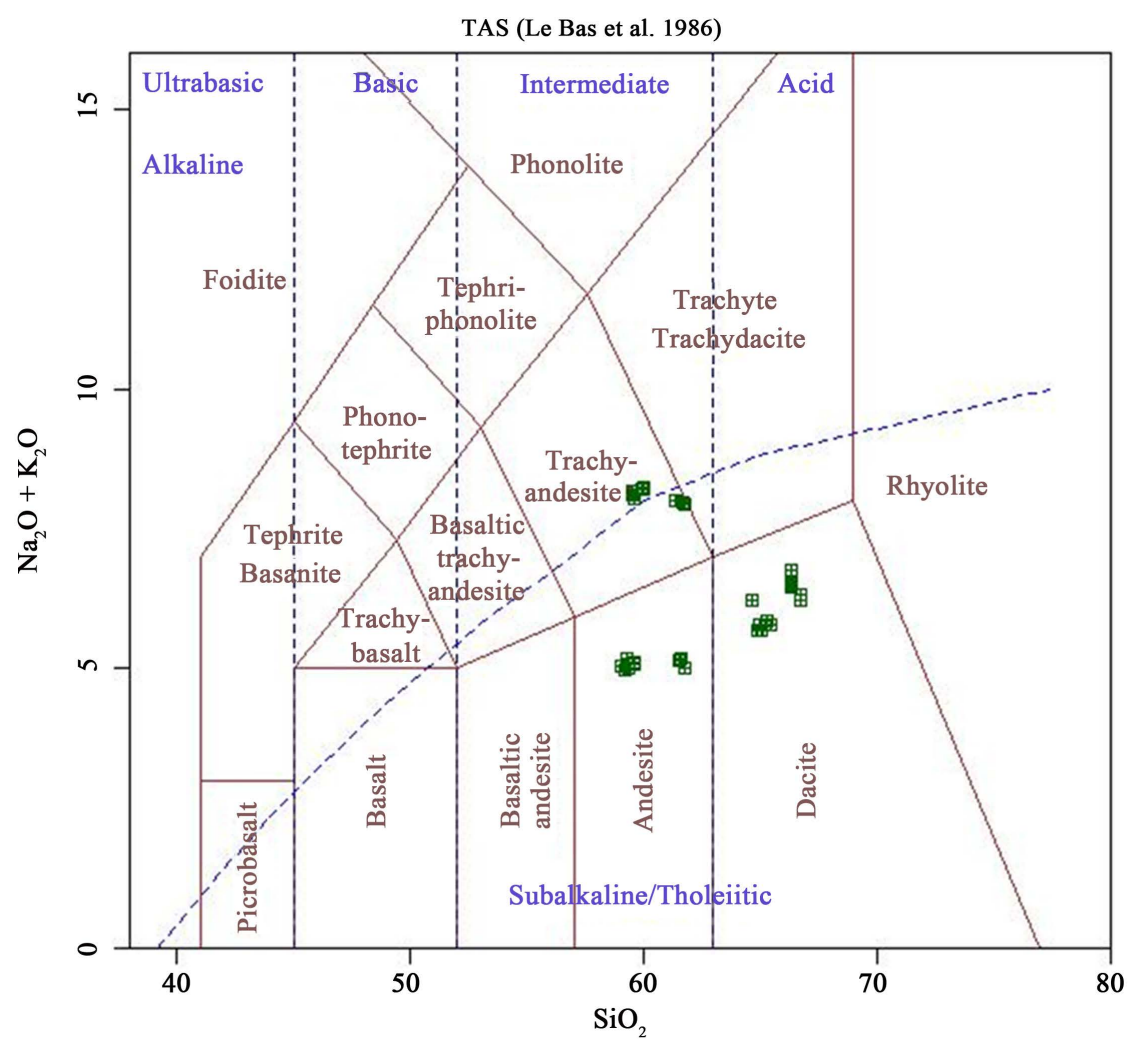

Figure 2. The position of Bidkhan rocks on Tas (Le Bas 1986) diagram.

TAS (Middlemost 1979)

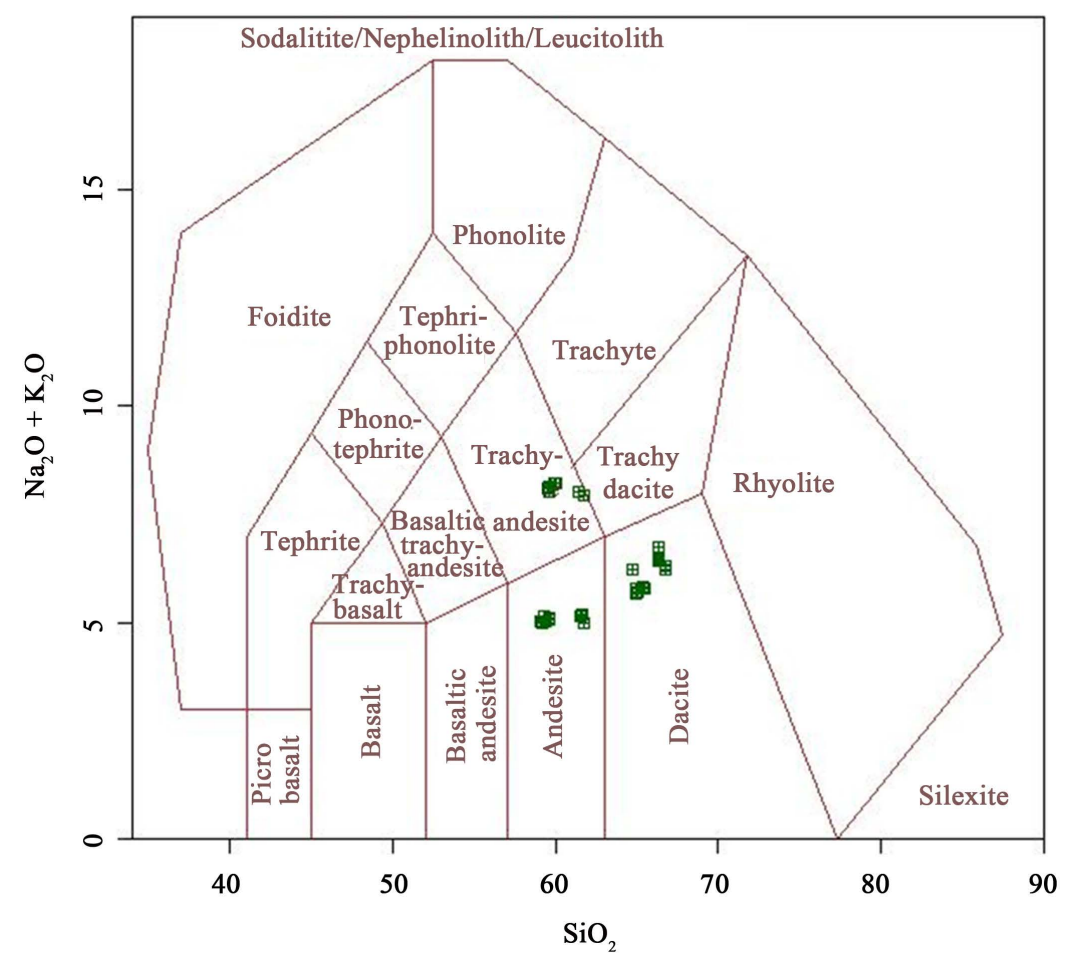

Figure 3. The position of Bidkhan rocks on Tas (Middle Most 1994) diagram. 


\section{Discussion}

The most important tectonic structures that exist are main, reverse, and relatively long quadruplet faults that have a northern-southern trend and movement. Fracture and minor faults of the strike slip with high density exist within the interstitial space of these main faults. In fact, Bidkhan valley is one of these main faults that are connected to the southern heights from its south side. This is the main fault of Bidkhan that have converted into the main drainage of Bidkhan catchment area over time. Width of this drainage has become extended because of mechanical weathering. Other main faults in Bidkhan area are also placed and observed in a direction similar to this valley fault. Total fracture networks created by main and minor faults allows for smooth movement of magmatic fluids. There is a severely altered integrated set of rocks in Bidkhan. Despite its youth, lithology and the events causing this set are remarkable. Important, various, and different events that have geochemical-geological aspects occur with high density in this area. All kinds of alterations along with sulfide stock works, leachings, and supergenes are among these events. It is also noteworthy to mention the phenomena of hot springs that make travertine and are located in the vicinity of this area (outside of Bidkhan region). They are a part of these evidence collections [11].

\section{Geochemistry and the Position of These Regional Rocks Based on Their Chemistry}

$\mathrm{R}_{1}, \mathrm{R}_{2}$ Plot (De La Roche 1980) diagram is adjusted according to the chemistry of these regional rocks (Figure 4). 30 analyzed samples, $\mathrm{R}_{1}=4 \mathrm{Si}-11(\mathrm{Na}+\mathrm{K})-2(\mathrm{Fe}+\mathrm{Ti})$ in the $\mathrm{x}$-axes and $\mathrm{R}_{2}=6 \mathrm{Ca}+2 \mathrm{Mg}+\mathrm{Al}$ in $\mathrm{y}$-axes were plotted on this diagram. These rocks were placed within three ranges of andesite, latite, dacite, and trachydacite with little differences, which is close to the observations for sections petrology.

On Harker diagram, main oxides were plotted against $\mathrm{SiO}_{2}$. Valuable information can be gained from the changing trend of these oxides compared to $\mathrm{SiO}_{2}$ increase. This diagram is presented in (Figure 5) and the following results were obtained:

1) $\mathrm{Na}_{2} \mathrm{O}$ with a negative slope, decreases with the increase of $\mathrm{SiO}_{2}$ and has a sharp (steep) slope. It was determined that generally in these three types of rocks, with the increase of silica, sodium is decreased. But more specifically, with the increase of silica, sodium is also increased with a gentle slope in each type.

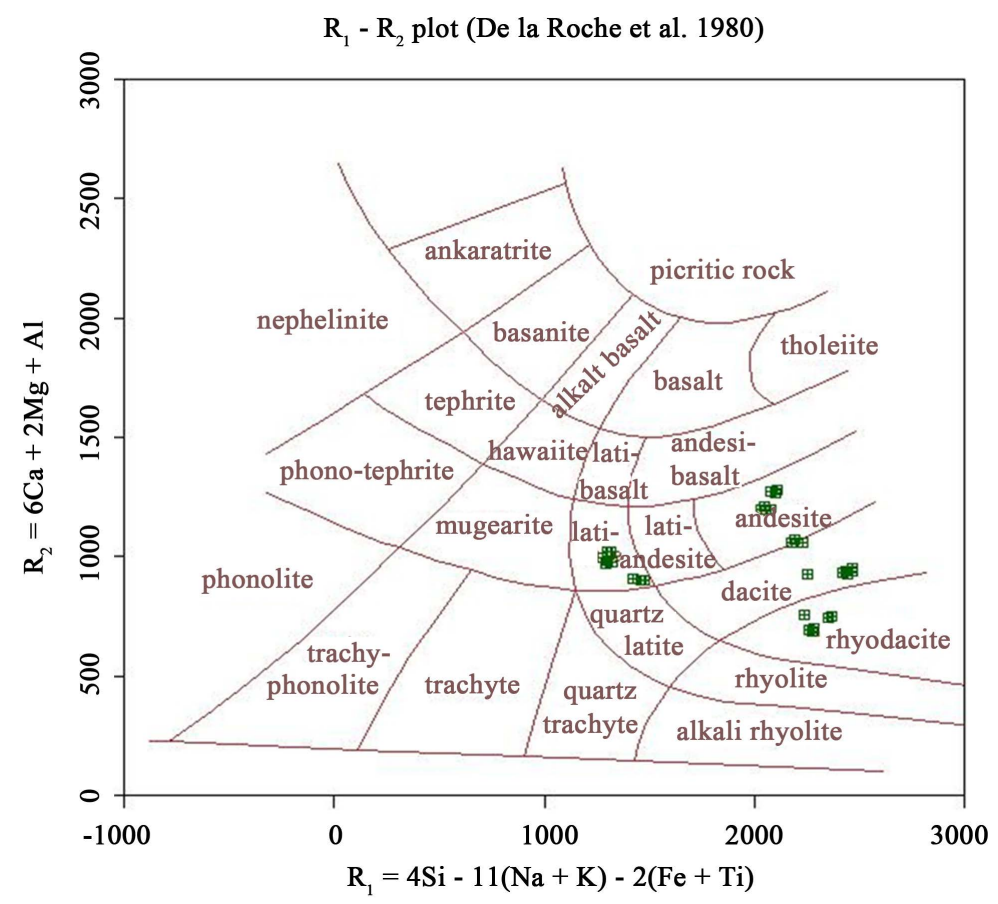

Figure 4. The position of Bidkhan rocks on R1, R2 Plot (De La Roche 1980) diagram. 

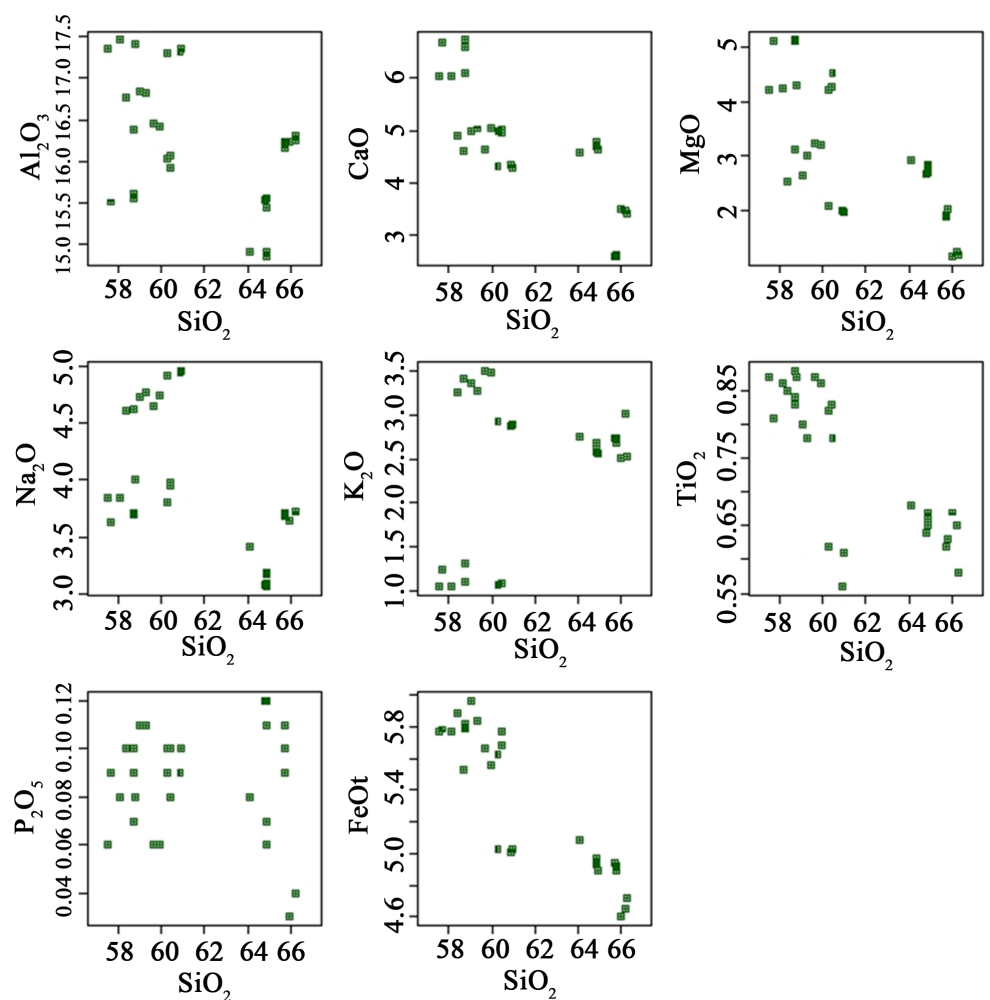

Figure 5. Harker diagram for Bidkhan rocks.

2) $\mathrm{K}_{2} \mathrm{O}$ can also be observed in three rock types of this diagram. This diagram demonstrates that andesitic rocks of this region do not show a significant change in the amount of potassium against the increase of $\mathrm{SiO}_{2}$. But other rocks of this region show a decrease in potassium with a gentle slope from the increase of silica.

3) $\mathrm{CaO}$ decreases in relation to the increase of silica with a steep slope.

4) $\mathrm{MgO}$ shows the same decrease slope of calcium in respect to the increase of silica.

5) $\mathrm{Al}_{2} \mathrm{O}_{3}$ shows an overall decrease, which means aluminium decreases with the increase of silica. With a more careful examination, it is evident that increase exists in all the separate types of rocks for this region. Andesitic rocks demonstrate positive gentle slope and dacite rocks demonstrate a positive steep slope.

6) $\mathrm{TiO}_{2}$ decreases with the increase of silica.

7) $\mathrm{FeO}$ or iron oxide also decreases with the increase of silica.

Therefore, it was concluded that even though the changing trends for main oxides of igneous rocks are somewhat linear and it actually shows magmatic differentiation in these rocks, factors such as alteration and magmatic contamination affected this trend (Table 1).

\section{Geochemistry and the Position of These Regional Rocks Based on Type of Magma}

As it was observed in the diagrams of previous section, rocks of this region are in the range of sub-alkaline, which also tend to alkaline. After plotting the 30 samples on Miashiro 1974 diagram for $\mathrm{SiO}_{2}$ on $\mathrm{x}$ and $\mathrm{y}$ $\mathrm{FeO}_{\mathrm{t}} / \mathrm{MgO}$ axes, it was observed that almost all the samples are in the range of calc-alkaline series (Figure 6).

Studying AFM diagram, which is a triangular diagram, showed that Bidkhan rocks are among calc-alkaline series (Figure 7). On this diagram, $\mathrm{A}=\left(\mathrm{K}_{2} \mathrm{O}+\mathrm{Na}_{2} \mathrm{O}\right), \mathrm{F}=\mathrm{FeO}_{\mathrm{t}}$ and $\mathrm{M}=\mathrm{MgO}$.

$\mathrm{SiO}_{2}-\mathrm{K}_{2} \mathrm{O}$ (Peccerillo \& Taylor 1976) diagram divides the magmatic series of Bidkhan rocks into two series. Andesitic rocks are calc-alkaline and the other rocks of this region are in the range of the above potassic calcalkaline series (Figure 8).

On $\mathrm{A} / \mathrm{CNK}-\mathrm{A} / \mathrm{NK}$ Plot (Shand 1943) diagram, $\mathrm{x}$-axes is $\mathrm{A} / \mathrm{NK}=\mathrm{AL}_{2} \mathrm{O}_{3} /\left(\mathrm{Na}_{2} \mathrm{O}+\mathrm{K}_{2} \mathrm{O}\right)$ and $\mathrm{y}$-axes is $\mathrm{A} / \mathrm{CNK}=\mathrm{AL}_{2} \mathrm{O}_{3} /\left(\mathrm{CaO}+\mathrm{Na}_{2} \mathrm{O}+\mathrm{K}_{2} \mathrm{O}\right)$. An examination of this diagram reveals that majority of these rocks are 
$\mathrm{SiO}_{2}-\mathrm{FeOt} / \mathrm{MgO}$ plot (Miyashiro 1974)

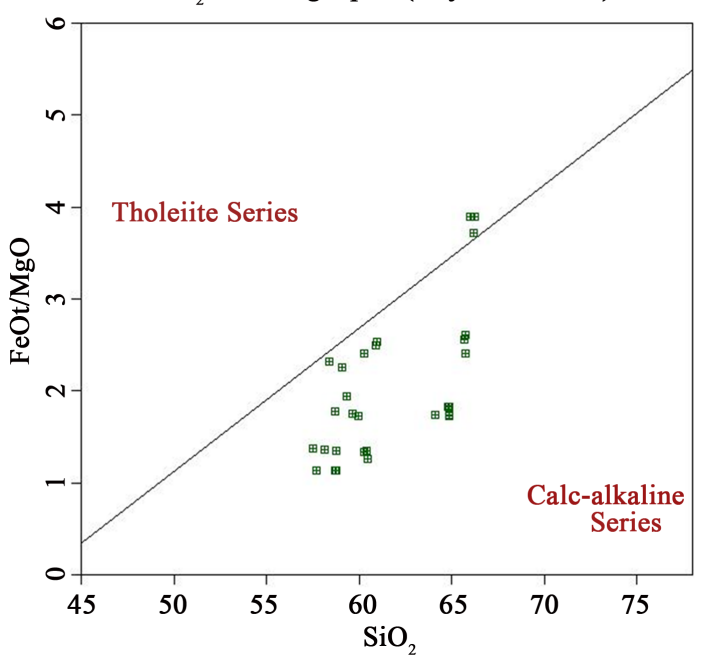

Figure 6. The position of Bidkhan rocks on Miashiro 1974 diagram.

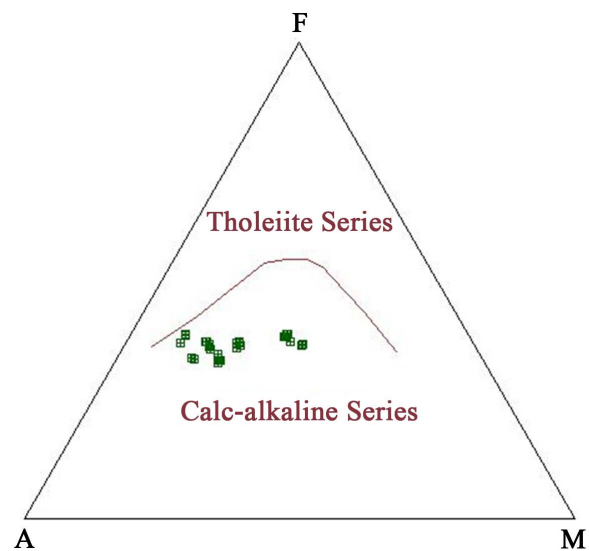

Figure 7. The position of Bidkhan rocks on AFM diagram.

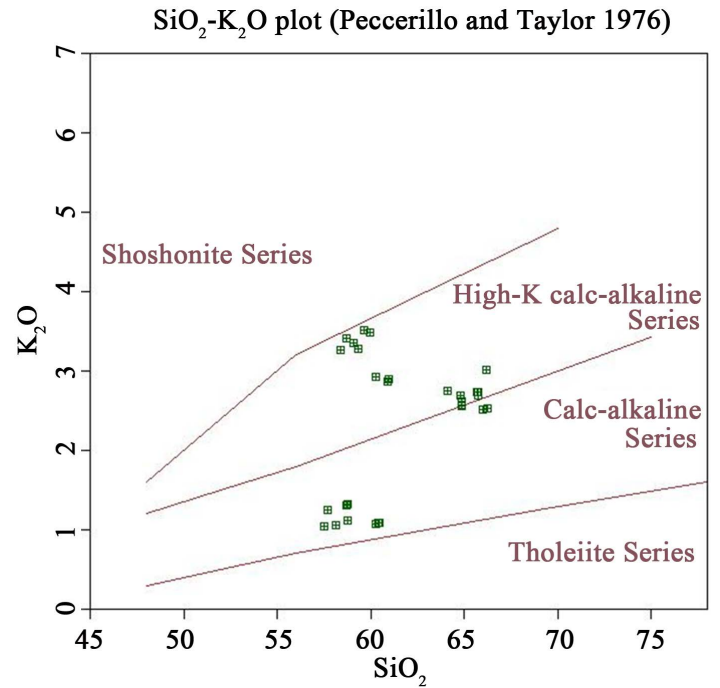

Figure 8. The position of Bidkhan rocks on $\mathrm{SiO}_{2}-\mathrm{K}_{2} \mathrm{O}$ (Peccerillo \& Taylor 1976) diagram. 
in the range of metaluminous rocks and some of them are in the range of peraluminous rocks (Figure 9). According to microscopic evidences, it can be concluded that this high level of aluminum in the rocks is due to the argillization and increase of aluminum by alteration (Table 1).

Geotectonic diagrams, which are triangular diagrams by (Pearce et al. 1977), are an attempt to study the type of magmatism in relation to tectonic processes. According to this diagram, magma source for the rocks of this region was caused by orogenry. Based on the existing information and this diagram, this magma was caused by the subduction of the oceanic crust under the continental crust (Figure 10) and (Table 1).

Table 1. The results of the analysis of main oxides for the retrieved petrological samples.

\begin{tabular}{|c|c|c|c|c|c|c|c|c|c|c|c|c|c|c|}
\hline \multicolumn{15}{|c|}{ Major oxide analyse result of fresh or slightly altered rock samples of subvolcanic-volcanic Bidkhan outcrops } \\
\hline No. & Sample No. & $\mathrm{SiO}_{2}$ & $\mathrm{Al}_{2} \mathrm{O}_{3}$ & $\mathrm{Fe}_{2} \mathrm{O}_{3}$ & $\mathrm{CaO}$ & MgO & $\mathrm{Na}_{2} \mathrm{O}$ & $\mathrm{K}_{2} \mathrm{O}$ & $\mathrm{Na}_{2} \mathrm{O}+\mathrm{K}_{2} \mathrm{O}$ & $\mathrm{MnO}$ & $\mathrm{TiO}_{2}$ & $\mathrm{P}_{2} \mathrm{O}_{5}$ & L.O.I & Total \\
\hline 1 & Kb.80.ch & 65.74 & 16.23 & 5.47 & 2.58 & 1.89 & 3.68 & 2.73 & 6.41 & 0.02 & 0.62 & 0.11 & $\mathrm{Nd}$ & 99.07 \\
\hline 2 & Kb.81.ch & 64.86 & 15.56 & 5.52 & 4.79 & 2.71 & 3.06 & 2.62 & 5.68 & 0.01 & 0.67 & 0.12 & 0.02 & 99.92 \\
\hline 3 & Kb.82.ch & 64.88 & 14.92 & 5.44 & 4.62 & 2.83 & 3.17 & 2.56 & 5.73 & 0.01 & 0.67 & 0.06 & $\mathrm{Nd}$ & 99.16 \\
\hline 4 & Kb.83.ch & 60.89 & 17.31 & 5.57 & 4.33 & 2.01 & 4.95 & 2.87 & 7.82 & 0.02 & 0.56 & 0.09 & $\mathrm{Nd}$ & 98.60 \\
\hline 5 & Kb.84.ch & 57.53 & 17.36 & 6.41 & 6.05 & 4.21 & 3.85 & 1.05 & 4.90 & 0.02 & 0.87 & 0.06 & 0.86 & 97.41 \\
\hline 6 & Kb.85.ch & 58.72 & 16.39 & 6.15 & 4.59 & 3.12 & 4.63 & 3.41 & 8.04 & 0.01 & 0.88 & 0.07 & 0.88 & 97.97 \\
\hline 7 & Kb.86.ch & 60.28 & 16.04 & 6.25 & 4.98 & 4.21 & 3.81 & 1.07 & 4.88 & 0.06 & 0.82 & 0.09 & 0.68 & 97.61 \\
\hline 8 & Kb.87.ch & 65.97 & 16.24 & 5.11 & 3.49 & 1.18 & 3.64 & 2.52 & 6.16 & 0.01 & 0.67 & 0.03 & $\mathrm{Nd}$ & 98.86 \\
\hline 9 & Kb.88.ch & 58.39 & 16.77 & 6.54 & 4.91 & 2.54 & 4.62 & 3.26 & 7.88 & 0.01 & 0.85 & 0.10 & $\mathrm{Nd}$ & 97.99 \\
\hline 10 & Kb.89.ch & 57.71 & 15.51 & 6.43 & 6.68 & 5.09 & 3.63 & 1.25 & 4.88 & 0.04 & 0.81 & 0.09 & $\mathrm{Nd}$ & 97.24 \\
\hline 11 & Kb.90.ch & 65.76 & 16.17 & 5.44 & 2.61 & 2.03 & 3.70 & 2.69 & 6.39 & 0.02 & 0.63 & 0.10 & 0.01 & 99.15 \\
\hline 12 & Kb.91.ch & 64.86 & 15.45 & 5.50 & 4.68 & 2.74 & 3.09 & 2.58 & 5.67 & 0.01 & 0.65 & 0.11 & 0.00 & 99.67 \\
\hline 13 & Kb.92.ch & 64.85 & 14.86 & 5.49 & 4.69 & 2.85 & 3.19 & 2.61 & 5.80 & 0.01 & 0.66 & 0.07 & 0.20 & 99.28 \\
\hline 14 & Kb.93.ch & 60.95 & 17.35 & 5.59 & 4.29 & 1.99 & 4.97 & 2.89 & 7.86 & 0.02 & 0.61 & 0.10 & 0.75 & 98.76 \\
\hline 15 & Kb.94.ch & 58.79 & 17.41 & 6.44 & 6.11 & 4.28 & 4.01 & 1.11 & 5.12 & 0.02 & 0.87 & 0.08 & 0.02 & 99.12 \\
\hline 16 & Kb.95.ch & 59.95 & 16.42 & 6.18 & 5.04 & 3.21 & 4.75 & 3.48 & 8.23 & 0.02 & 0.86 & 0.06 & 0.01 & 99.97 \\
\hline 17 & Kb.96.ch & 60.43 & 15.93 & 6.41 & 5.01 & 4.27 & 3.98 & 1.09 & 5.07 & 0.05 & 0.83 & 0.1 & 0.72 & 98.10 \\
\hline 18 & Kb.97.ch & 66.21 & 16.31 & 5.17 & 3.47 & 1.25 & 3.72 & 3.01 & 6.73 & 0.01 & 0.65 & 0.04 & 0 & 99.84 \\
\hline 19 & Kb.98.ch & 59.30 & 16.83 & 6.49 & 5.03 & 3.01 & 4.78 & 3.28 & 8.06 & 0.01 & 0.78 & 0.11 & 0.02 & 99.62 \\
\hline 20 & Kb.99.ch & 58.75 & 15.55 & 6.45 & 6.74 & 5.11 & 3.69 & 1.32 & 5.01 & 0.04 & 0.84 & 0.09 & 0.53 & 98.58 \\
\hline 21 & Kb.100.ch & 65.70 & 16.21 & 5.49 & 2.59 & 1.93 & 3.71 & 2.74 & 6.45 & 0.02 & 0.62 & 0.09 & 0.04 & 99.10 \\
\hline 22 & Kb.101.ch & 64.81 & 15.53 & 5.48 & 4.7 & 2.69 & 3.08 & 2.69 & 5.77 & 0.01 & 0.64 & 0.12 & 0.01 & 99.75 \\
\hline 23 & Kb.102.ch & 64.09 & 14.91 & 5.65 & 4.58 & 2.92 & 3.41 & 2.75 & 6.16 & 0.02 & 0.68 & 0.08 & 0.02 & 99.09 \\
\hline 24 & Kb.103.ch & 60.28 & 17.3 & 5.59 & 4.32 & 2.09 & 4.93 & 2.93 & 7.86 & 0.02 & 0.62 & 0.1 & 0.78 & 98.18 \\
\hline 25 & Kb.104.ch & 58.13 & 17.46 & 6.41 & 6.04 & 4.25 & 3.84 & 1.06 & 4.90 & 0.06 & 0.86 & 0.08 & 0.5 & 98.19 \\
\hline 26 & Kb.105.ch & 59.67 & 16.45 & 6.3 & 4.63 & 3.24 & 4.65 & 3.51 & 8.16 & 0.02 & 0.87 & 0.06 & 0.87 & 99.40 \\
\hline 27 & Kb.106.ch & 60.45 & 16.07 & 6.32 & 4.96 & 4.52 & 3.95 & 1.09 & 5.04 & 0.05 & 0.78 & 0.08 & 0.64 & 98.27 \\
\hline 28 & Kb.107.ch & 66.25 & 16.25 & 5.24 & 3.39 & 1.21 & 3.73 & 2.53 & 6.26 & 0.02 & 0.58 & 0.04 & 0.06 & 99.24 \\
\hline 29 & Kb.108.ch & 59.05 & 16.84 & 6.63 & 4.99 & 2.64 & 4.73 & 3.36 & 8.09 & 0.01 & 0.8 & 0.11 & 0.01 & 99.16 \\
\hline 30 & Kb.109.ch & 58.73 & 15.61 & 6.47 & 6.59 & 5.12 & 3.71 & 1.31 & 5.02 & 0.04 & 0.83 & 0.1 & 0.39 & 98.51 \\
\hline
\end{tabular}




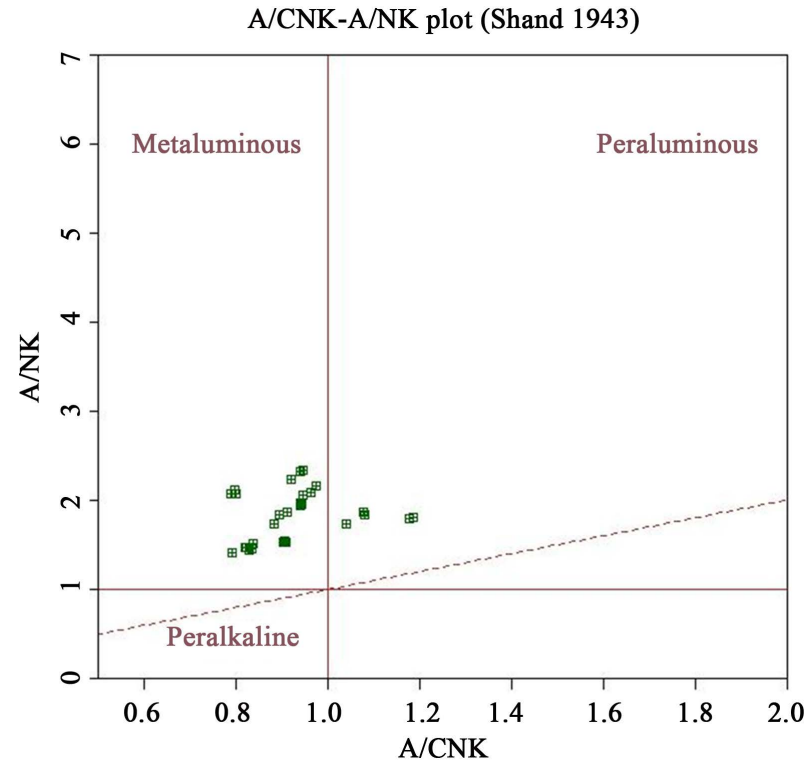

Figure 9. The position of Bidkhan rocks on A/CNK-A/NK Plot (Shand 1943) diagram.

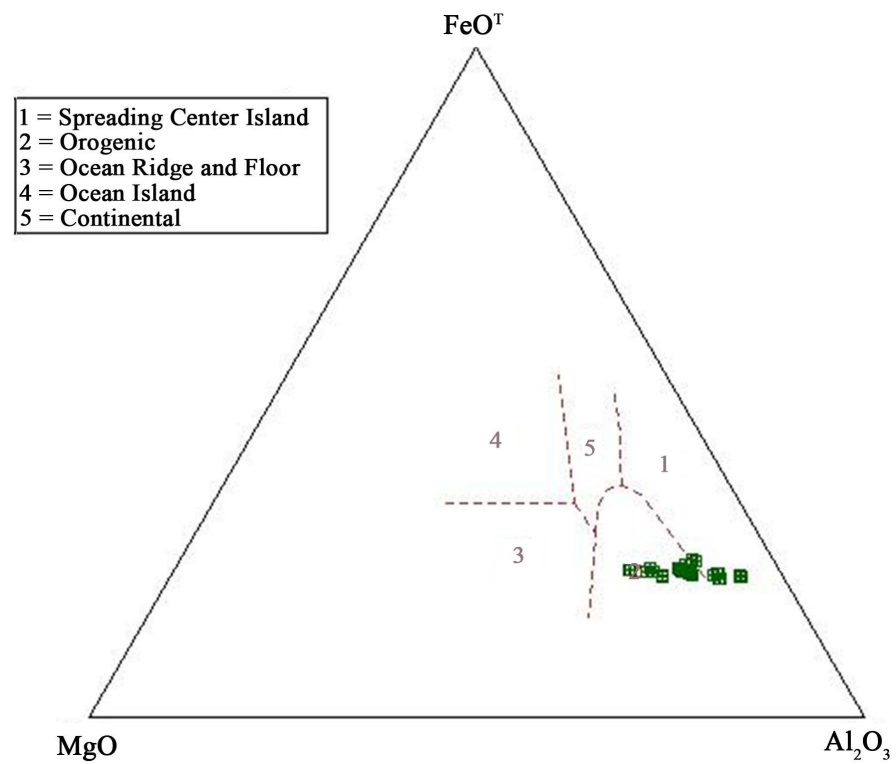

Figure 10. The position of Bidkhan rocks in relation to the source tectonic processes for magmatism.

\section{Malachitization}

Even in small quantities, the existence of azurite and malachite in an exploration area has significant exploratory value. The importance of malachite is not only due to being a remarkable mineral in exploration and foundation activities, but also mostly because of the importance of a process known as malachitization. Impacts of malachitization can be observed in many areas of Bidkhan. The analogous phenomena in the malachite outcrops of these regions is feldspar crystals that are converted into a set of secondary minerals such as sericite, illite, and other clay minerals and amphibole crystals are completely altered and their framework is filled up by malachite. There is also malachite within frameworks of some feldspar crystals. Secondary minerals of the outcrops from these regions consist of sericite, illite, clay minerals, malachite, apak, oxides-hydroxides of iron, chlorite, epidote and quartz (Figure 11) [12]. 


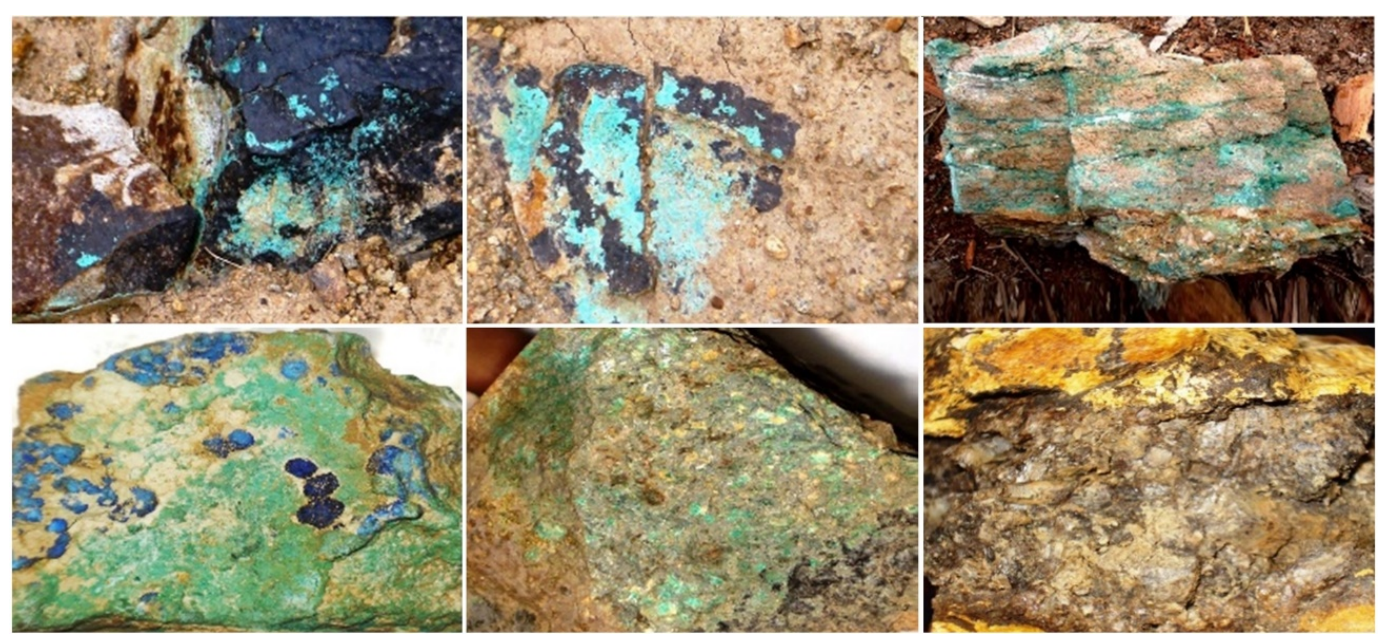

Figure 11. The process of malahitization in the rocks of Bidkhan region and close view of azurite, malachite, and formation of geode in pores of rocks.

\section{Geodes and Porous Quartzes Caused by Subsidence}

The process for the formation of porous quartzes is a kind of alteration which is observed in Bidkhan along with geodes. In this kind of alteration, the empty space between quartz grains is partially filled with all kidns of minerals. This alteration is caused by the reaction between acidic fluids and the surrounding rocks and leads to the loss of the majority of constituents except for quartz and rutile parts. Places around alteration zones are the best location for observing porous quartzes. Many hand samples and also petrographic and mineralographic samples of Bidkhan region demonstrate alteration of quartz (porous). By moving from the region of alteration for porous quartz into the alteration region, many alterations such as quartz-alunite, quartz-kaolinite, and even perhaps pyrophyllite can be reached. Geodes are also valuable for exploratory studies along with the other evidences. Such geodes are also found in Bidkhan's set. Alteration of porous quartz is usually created in the center and core of many ores and $\mathrm{Au}-\mathrm{Cu}$ mineralization-with high sulphidation. In addition, these evidence can be observed in the upper parts of some porphyry ores and also in epithermal environments. Many traces of subsidence exist in Bidkhan and since faults play the main role in geological fluid dynamics, traces of subsidence are seen in fault zones. Since Bidkhan region has a significant density of main and secondary faults, almost all the central parts of Bidkhan bear traces of subsidence within themselves. These traces have different dimensions, from centimeters up to meters wide. The hand sample presented in the following figure shows pores that are caused by subsidence and are filled with silica, oxide, and iron hydroxides. Sometimes, these pores and cavities are also filled with malachite and azurite crystals (Figure 12).

\section{Results}

1) Morphology of Bidkhan resembles a ring shape or a ring structure of huge dimensions with several tens of kilometers. This huge ring in the outside edge is very lofty, which is quickly converted into a foothill towards the central direction with a negative steep slope (Figure 13).

2) Based on the Ore-Mineral findings in Bidkhan region, it can be concluded that "erosion surface" includes the central part and is shaped like a ring around the central and upper part of leaching zone. Erosion surface is for all the surfaces of the central part of Bidkhan. By performing deep excavations, some parts could be reached in which minerals and other related and expected sets exist in the supergene zone (Figure 13).

3) Folds have an almost northwest-southeast trend. The impacts of these folds can mostly be seen on the parts that are outside the studied region of Bidkhan. Considering that this region is located in a way that its surrounding units are all folded symmetrically, it can be concluded that this symmetry is in accordance with positioning of an intrusive body (rocks) in the central section of Bidkhan. Due to the homogenous tension caused by this symmetrical uplift, folded surrounding units became symmetrical and they were folded in a dome shaped pattern. This dome shaped pattern folding can be observed across the heights surrounding the central part of Bidkhan (Figure 14). 

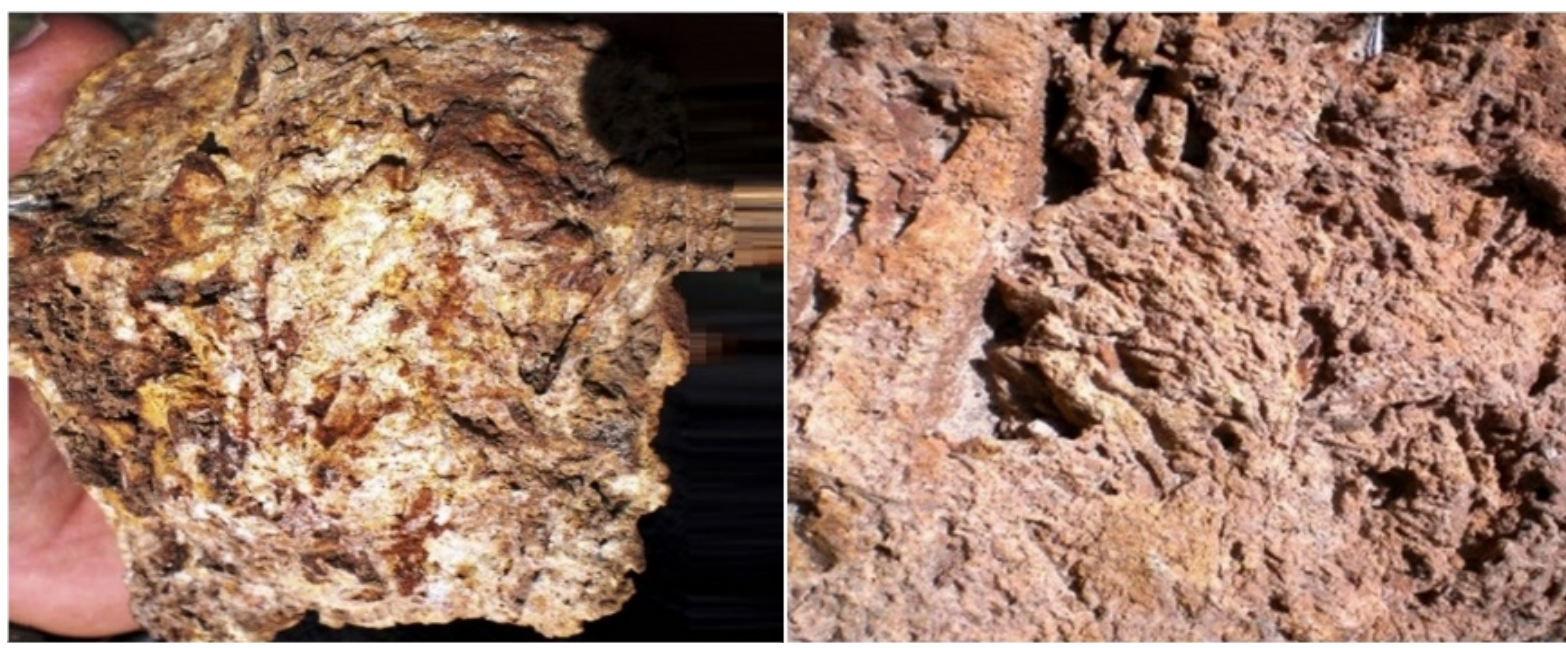

Figure 12. Pores caused by subsidence and filled with silica, oxides and hydroxides of iron and dissolution of all minerals and formation of quartz grains and silicic veinlets.
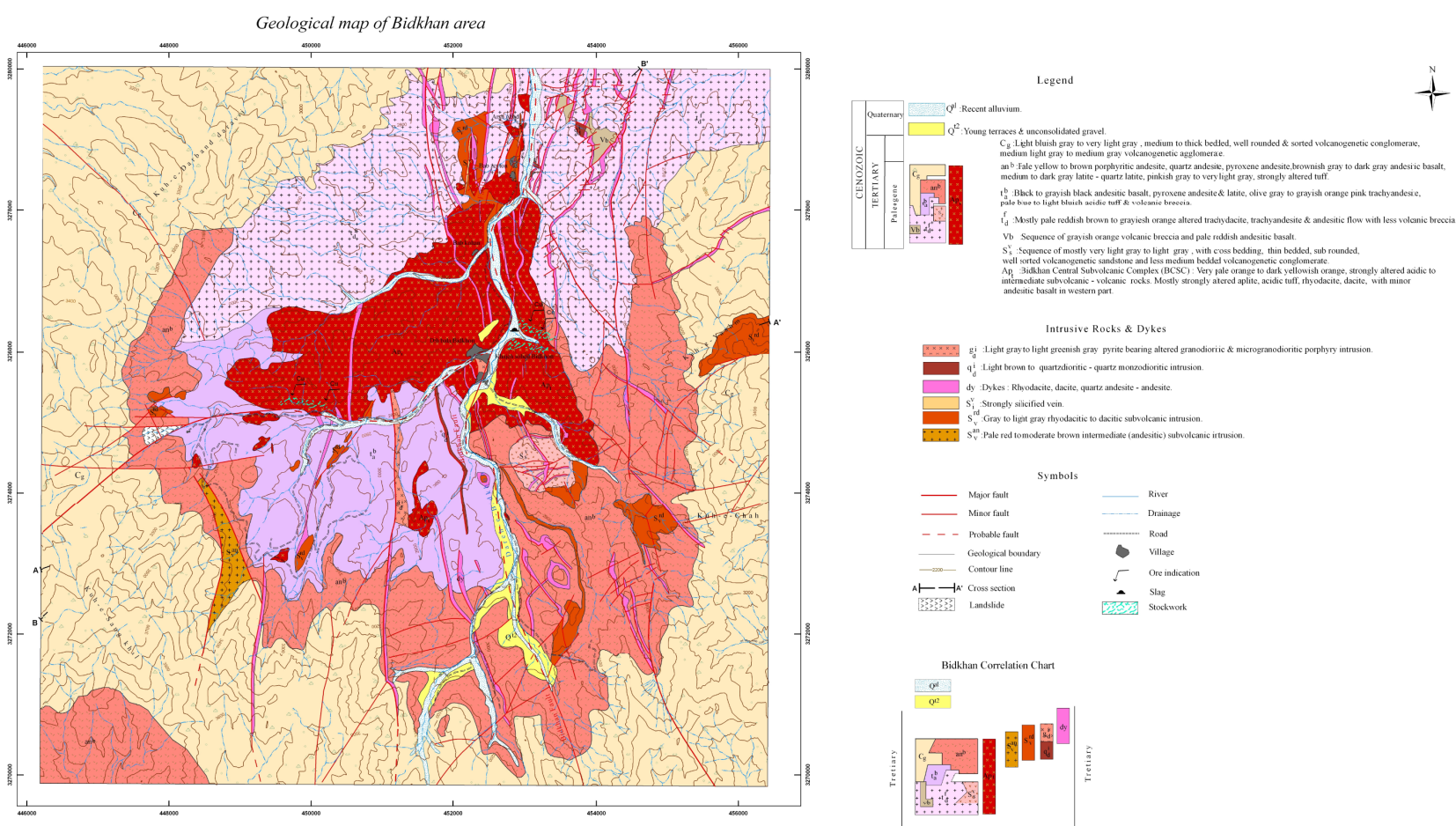

Figure 13. Geological map of bidkhan area (scale 1:25,000).

4) Lithology of Bidkhan can be divided into 5 parts: Central part, middle volcaninc ring or belt, svsfacies, "unit $C_{g}$ " external volcanogenic part, dykes and intrusive rocks and quartz deposits. $C_{g}$ unit forms the heights of Bidkhan region. Heights are practically insurmountable due to their outward steep slope. $C_{g}$ unit is extended in all directions and also extends to far distances from Bidkhan region. Based on the existing evidence, nomenclature of Bidkhan under the name of "Bidkhan’s Caldera” is a controversial subject. Simply existing the morphology similar to a caldera cannot be a good reason for this nomenclature. On the contrary, there are numerous evidences that make the caldera of Bidkhan ambiguous. $C_{g}$ unit is not a Lahar but rather a conglomerate and a cutting, although, determination of this very subject also requires research and academic projects to be carried out. In addition to the common mechanism for the creation of caldera, there is a possibility that formation of dome shaped structure for Bidkhan is caused by uplift and positioning of an intrusive body. With this presump- 


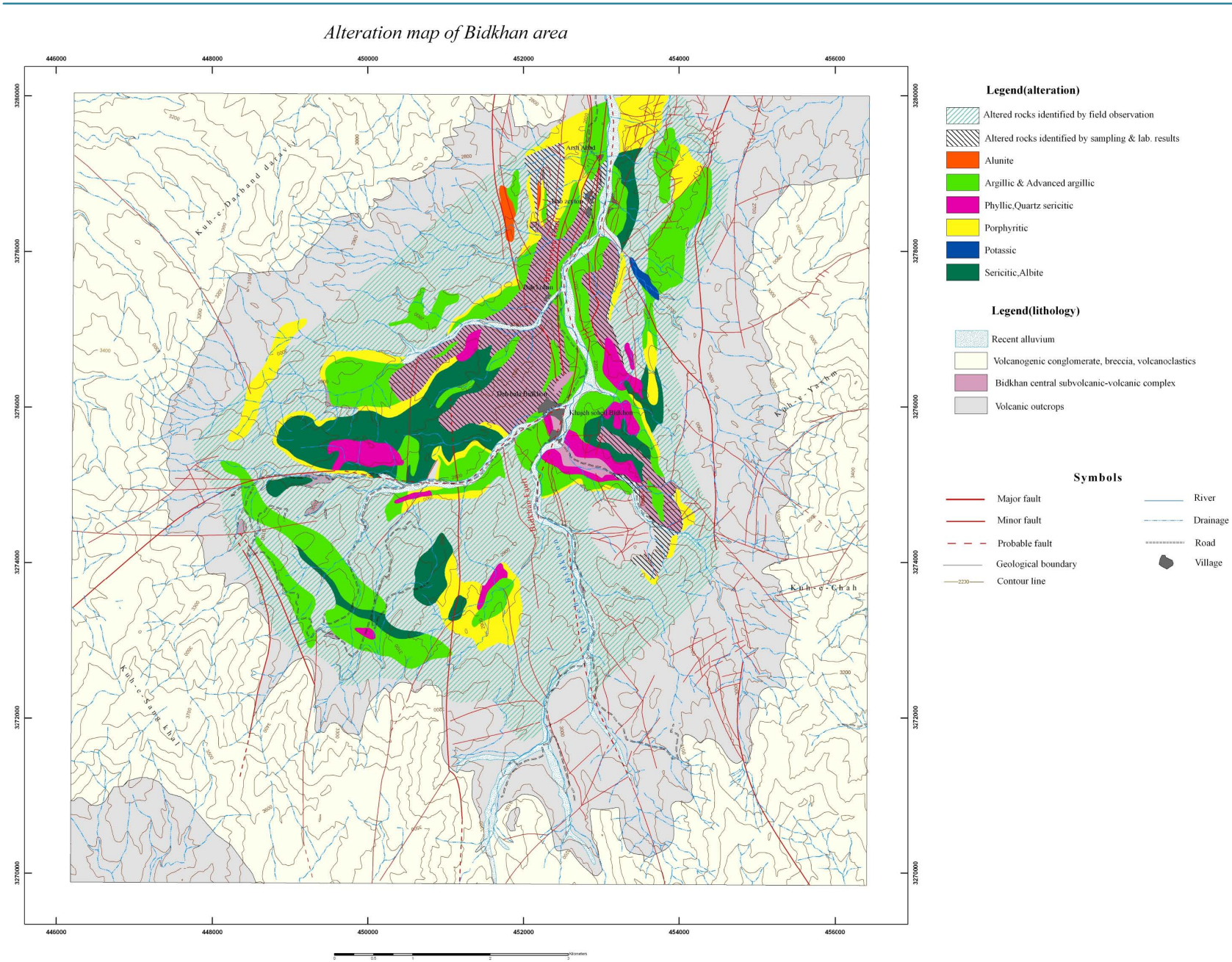

Figure 14. Alteration map of bidkhan area (scale 1:25,000).

tion, the igneous outcrops existing in Bidkhan region can be considered the product of the same igneous source activities. According to the age of the available units in Bidkhan's caldera and their method of deformation, it can be concluded that late alpine orogeny phases cause the creation of the current structural condition of Bidkhan region (Figure 14).

\section{Acknowledgements}

The authors thank Islamic Azad University South Tehran branch for support of this research. This paper presents the research project entitled "Rapture and Land Deformation Statistical Analysis for Earthquake along the Selected Active Fault in Central Iran” is extracted.

\section{References}

[1] Berberian, M. and King, G.C.P. (1981) Towards a Paleogeography and Tectonic evolution of Iran. Canadian Journal of Earth Sciences, 18, 210-265. http://dx.doi.org/10.1139/e81-019

[2] Meyer, B. and Le Dortz, K. (2007) Strike-Slip Kinematics in Central and Eastern Iran: Estimating Fault Slip-Rates Averaged over the Holocene. Tectonics, 26, TC5009, 20 p.

[3] Walker, R.T. (2006) A Remote Sensing Study of Active Folding and Faulting in Southern Kerman Province, S.E. Iran. Journal of Structural Geology, 28, 654-668. http://dx.doi.org/10.1016/j.jsg.2005.12.014

[4] Walker, R.T., Gans, P., Allen, M.B., Jackson, J., Khatib, M., Marsh, N. and Zarrinkoub, M. (2009) Late Cenozoic 
Volcanism and Rates of Active Faulting in Eastern Iran. Geophysical Journal International, 177, 783-805. http://dx.doi.org/10.1111/j.1365-246X.2008.04024.x

[5] Walker, R. and Jackson, J. (2004) Active Tectonics and Late Cenozoic Strain Distribution in Central and Eastern Iran. Tectonics, 23, TC5010. http://dx.doi.org/10.1029/2003TC001529

[6] Ashofteh, A. and Adib, A. (2014) Primitive Studies for Copper Deposit in Bidkhan Copper Mine with Regards to Wide Survey of Altered Areas and Mineral Indexes. Journal of Middle East Applied Science and Technology, 4, 86-90.

[7] Feizi, F. and Ashofteh, A. (2014) Area Exploration Takhte Soleiman Based on Geophysical and Satellite Imagery. Journal of Middle East Applied Science and Technology, 3, 414-417.

[8] Keshavarzi, R., Esmaili, D., Rezaei Kahkhaei, M., Asghar Mokhtari, M. and Jabari, R. (2014) Petrology, Geochemistry and Tectonomagmatic Setting of Neshveh Intrusion (NW Saveh). Open Journal of Geology, 4, 177-189. http://dx.doi.org/10.4236/ojg.2014.45013

[9] VaeziNejad, S., Tofigh, M. and Marandi, S. (2011) Zonation and Prediction of Land Subsidence (Case Study-Kerman, Iran). International Journal of Geosciences, 2, 102-110. http://dx.doi.org/10.4236/ijg.2011.22011

[10] Jafari, H. and Yazdi, A. (2014) Radioactive Anomalies in 1:50,000 Dehbakri Sheet, South of Kerman Province, Iran. Open Journal of Geology, 4, 399-405. http://dx.doi.org/10.4236/ojg.2014.48031

[11] SabokKhiz, H., MemarKocheBagh, A. and Hekmatian, M. (2015) Area Exploration Based on Airborne Radiometric Geophysical Data by Surfer Software at Rizab (the South East of Ardakan). Journal of Biodiversity and Environmental Sciences, 6, 761-767.

[12] Adib, A., Afzal, P. and Heydarzadeh, K. (2014) Site Effect Classification Based on Microtremor Data Analysis Using Concentration-Area Fractal Model. Nonlinear Processes in Geophysics (NPG), 22, 53-63. 